\title{
Evaluation of shear bond strength of different treatments of ceramic bracket surfaces
}

\author{
Patrícia Helou Ramos Andrade', Rogério Vieira Reges², Marcos Augusto Lenza ${ }^{3}$
}

Objective: To evaluate the bonding strength of the ceramic bracket and composite resin restoration interface, using four types of treatment on the base of the bracket.

Methodology: 48 photoactivated composite resin discs were used (Filtek ${ }^{\mathrm{TM}} \mathrm{Z} 250$ ) contained in specimens and divided into 4 groups of 12 specimens for each group according to the type of treatment performed on the base of the brackets. Once the brackets were bonded, the specimens were subjected to shear stress carried out in a universal testing machine (MTS: 810 Material Test System) calibrated with a fixed speed of $0.5 \mathrm{~mm} /$ minute. The values obtained were recorded and compared by means of appropriate statistical tests - analysis of variance and then Tukey's test.

Results and conclusions: The surfaces of ceramic brackets conditioned with $10 \%$ hydrofluoric acid for 1 minute, followed by aluminum oxide blasting, $50 \mu$, after silane application and primer application, was considered the best method to prepare surfaces of ceramic brackets prior to orthodontic esthetic bonding.

Keywords: Ceramic bracket. Composite. Shear strength.

${ }^{1}$ Specialist in Orthodontics, Funorte.

${ }^{2}$ Head Professor, Dental Materials and Restorative Dentistry - Paulista University (UNIP-GO). MSc and PhD in Dental Materials, FOP -University of Campinas (UNICAMP).

${ }^{3}$ Head Professor, Department of Orthodontics, and Chairman of the Graduate Program in Orthodontics - School of Dentistry - Federal University of Goiás (UFG).
How to cite this article: Andrade PHR, Reges RV, Lenza MA. Evaluation of shear bond strength of different treatments of ceramic bracket surfaces. Dental Press J Orthod. 2012 July-Aug;17(4):17.el-8.

Submitted: August 6, 2008 - Revised and accepted: January 26, 2009

" The authors report no commercial, proprietary or financial interest in the products or companies described in this article.

Contact address: Patrícia Helou Ramos Andrade Rua QRSW 4, bloco B8, apto. 303 - Sudoeste - Brasília / DF, Brazil Zip code: 70.675-428 - E-mail: patricia_helou@yahoo.com.br 


\title{
Avaliação da resistência ao cisalhamento de diferentes tratamentos na superfície de braquetes cerâmicos
}

\author{
Patrícia Helou Ramos Andrade', Rogério Vieira Reges², Marcos Augusto Lenza ${ }^{3}$
}

Objetivo: avaliar a resistência à união da interface entre braquete cerâmico e restauração de resina composta, empregando quatro tipos de tratamento na base do braquete.

Métodos: foram utilizados 48 discos de resina fotoativada (Filtek ${ }^{\circledR}$ Z250) incluídos em corpos de prova, divididos em quatro grupos, com 12 espécimes em cada grupo, de acordo com o tipo de tratamento realizado na base do braquete. Uma vez colados os braquetes, os corpos de prova foram submetidos à tensão de cisalhamento, realizado numa máquina universal de ensaios (MTS: 810 Material Test System) calibrada com velocidade fixa de 0,5mm/min. Os valores obtidos foram registrados e comparados por meio de médias, utilizando-se testes estatísticos adequados (análise de Variância e, posteriormente, teste de Tukey).

Resultados e Conclusões: o condicionamento das superfícies dos braquetes cerâmicos com ácido hidrofluorídrico a $10 \%$ por 1 minuto, seguido do jateamento com óxido de alumínio com 50um de tamanho, e posterior aplicação do silano e, depois, aplicação de adesivo, foi considerado o melhor método para o preparo de superfícies de braquetes cerâmicos previamente à colagem estética ortodôntica.

Palavras-chave: Braquete cerâmico. Compósito. Cisalhamento.

${ }^{1}$ Especialista em Ortodontia pela Faculdade Unidas do Norte de Minas/ Funorte.

${ }^{2}$ Professor Titular da disciplina de Materiais Dentários e Dentística na UNIP-GO. Mestre e Doutor em Materiais Dentários, FOP-UNICAMP - SP.

${ }^{3}$ Professor Titular da disciplina de Ortodontia e Coordenador do Curso de Especialização em Ortodontia na Faculdade de Odontologia da Universidade Federal de Goiás (UFG).
Como citar este artigo: Andrade PHR, Reges RV, Lenza MA. Evaluation of shear bond strength of different treatments of ceramic bracket surfaces. Dental Press J Orthod. 2012 July-Aug;17(4):17.el-8.

Enviado em: 6 de agosto de 2008 - Revisado e aceito: 26 de janeiro de 2009

» Os autores declaram não ter interesses associativos, comerciais, de propriedade ou financeiros que representem conflito de interesse nos produtos e companhias descritos nesse artigo.

Endereço para correspondência: Patrícia Helou Ramos Andrade Rua QRSW 4, bloco B8, apto. 303 - Sudoeste - CEP: 70.675-428 - Brasília / DF E-mail: patricia_helou@yahoo.com.br 


\section{INTRODUCTION}

The fixed appliance therapy in the current aspect presents itself with a variety of materials and techniques which aims to streamline the treatment seeking functionality and esthetics. One of the challenges for the professional in terms of technique and materials is the union of orthodontic attachments to teeth with esthetic restorations, either composite resin or ceramic. In contrast, patients seek in orthodontic treatment quality associated with esthetics. Thus, the introduction of the technique of direct union with adhesive binder materials initiated a trend to more esthetic orthodontic appliances. ${ }^{8}$

In the mid-80s, the first esthetic ceramic brackets became widely avaiable. ${ }^{8}$ According to the manufacturing process, ceramic brackets may have two types of composition: Monocrystalline and polycrystalline. The polycrystalline ceramic brackets or with polycrystalline alumina are constituted of aluminum oxide crystals fused at high temperatures, which enables the simultaneous production of several brackets. They are most common for the quality of their material and the relative easy production, compared with the alumina monocrystalline brackets. ${ }^{14,28}$

The monocrystalline ceramic brackets constitute in a molten mass at high temperature $\left(2100^{\circ} \mathrm{C}\right)$, forming a single aluminum oxide crystal resulting in the manufacture of a single bracket, making the production more expensive than the polycrystalline ones. However, this machining way has a lower incorporation of impurities, giving the parts highest tensile strength and lower opacity, making them particularly esthetic. ${ }^{14}$

The main constitution of the ceramic brackets is aluminum oxide $\left(\mathrm{Al}_{2} \mathrm{O}_{3}\right)$, giving them characteristics such as high hardness, resistance to high temperatures and chemical degradation and friability, with propagation of flaws by impurities or imperfections. ${ }^{14}$

The ceramic brackets are superior to the polycarbonate esthetic brackets due to the higher mechanical strength, increased esthetic and for showing less discoloration on the surface; but may have significant drawbacks such as increased frictional resistance to the metal archwires and difficulty for removal from tooth structure. ${ }^{8,14}$

Currently, to compensate the frictional constraints, some types of brackets show metal slots and others present a particular treatment in the slot surface, providing reduced friction and rounded edges to facilitate archwires sliding. ${ }^{14}$

There are factors that may favor the union of this substrate, such as the production of irregularities in the ceramic bracket base by means of blasting with $50 \mu \mathrm{m}$ aluminum oxide particles, which improve mechanical retention, ${ }^{28}$ allowing the bonding of brackets or accessories on these materials, which can reduce or substitute the use of bands over prostheses and any kind of restauration. ${ }^{19}$

Thus, this study aims to analyze through shear bond testing on the ceramic bracket/composite interface, the different types of treatment on the ceramic bracket basis prior to bonding.

\section{MATERIALS AND METHODS}

In this study were made 48 disks of photoactivated composite with dimensions of $10 \mathrm{~mm}$ (diameter) $\mathrm{x}$ $5 \mathrm{~mm}$ (height), divided into 4 groups of 12 specimens each one following the recommendations of the manufacturer (Fig 1). The procedures for the sample preparation followed the protocol established by the International Organization for Standardization (ISO), in the TR 114059 specification. The specimens were embedded in metal tubes with internal diameter of $11 \mathrm{~mm}$ by $13 \mathrm{~mm}$ tall, centralized with chemically activated acrylic resin (Jet Set, Clássico) (Fig 2). Then the ceramic brackets (Roth - slot $0.022 \times$ 0.018-in - Tecnident Orthodontic Equipment Ltda. - São Carlos / SP - Brazil) were fixed to the surface of composite resins (Filtek ${ }^{\mathrm{TM}} \mathrm{Z} 250$ ), following the types of bonding treatment of ceramic and composite resin, divided into 4 groups of samples:

Group I: The surfaces of ceramic brackets were etched with $\mathrm{FGM}^{\mathrm{TM}} 10 \%$ hydrofluoric acid (HF) for 1 minute, rinsed for 30 seconds and dried with oil-free air spray (Fig 3).

Group II: The surfaces of ceramic brackets were blasted with $50 \mu \mathrm{m}$ aluminum oxide for 10 seconds with a pressure of 2 bar (Fig 4 ).

Group III: The surfaces of ceramic brackets were etched with $\mathrm{FGM}^{\mathrm{TM}} 10 \%$ hydrofluoric acid for 1 minute, rinsed for 30 seconds and dried with oil-free air spray. They were then blasted with aluminum oxide $50 \mu \mathrm{m}$ for 10 seconds with a pressure of 2 bar (Fig 5).

Group IV: In the ceramic brackets surfaces were made prophylaxis with brush and pumice, rinsed for 30 seconds and dried with oil-free air spray (control group) (Fig 6). 


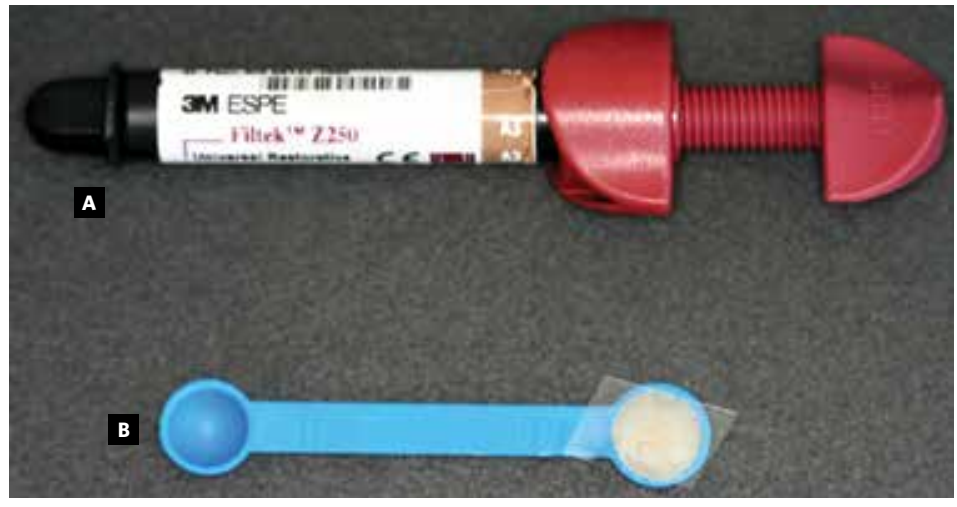

Figure 1 - A) Tube containing Filtek ${ }^{\mathrm{TM}} \mathrm{Z} 250$ composite resin. B) Composite resin disc.
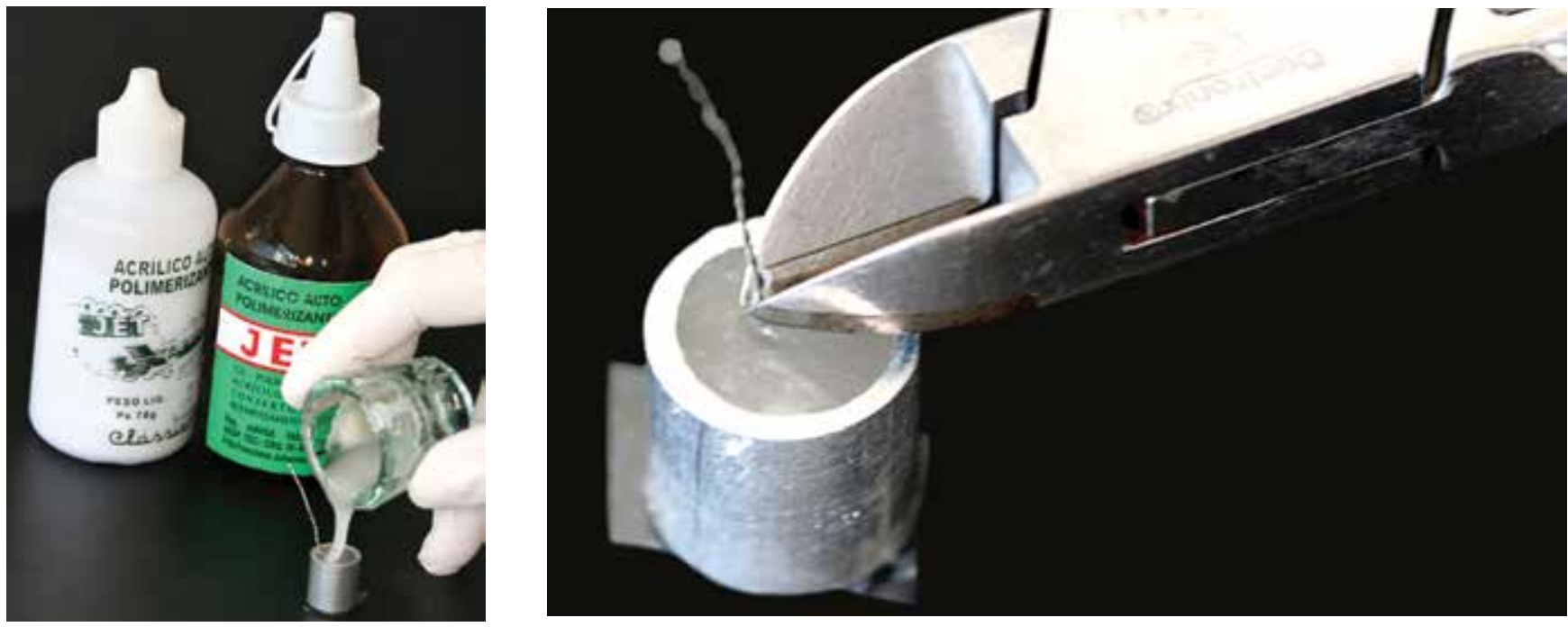

Figure $\mathbf{2}$ - Specimens included in the metal tube.
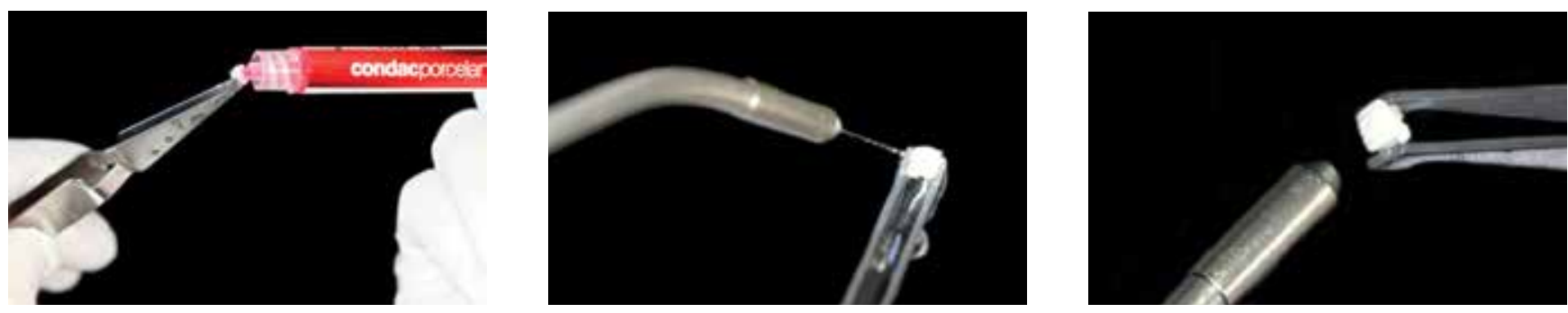

Figure 3 - Application of 10\% hydrofluoric acid followed by rinsing and drying.

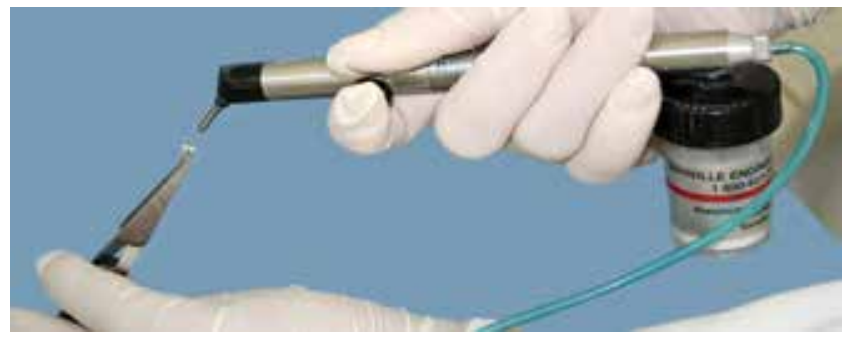

Figure 4 - Blasting with 50 $\mu \mathrm{m}$ aluminum oxide on the bracket base. 

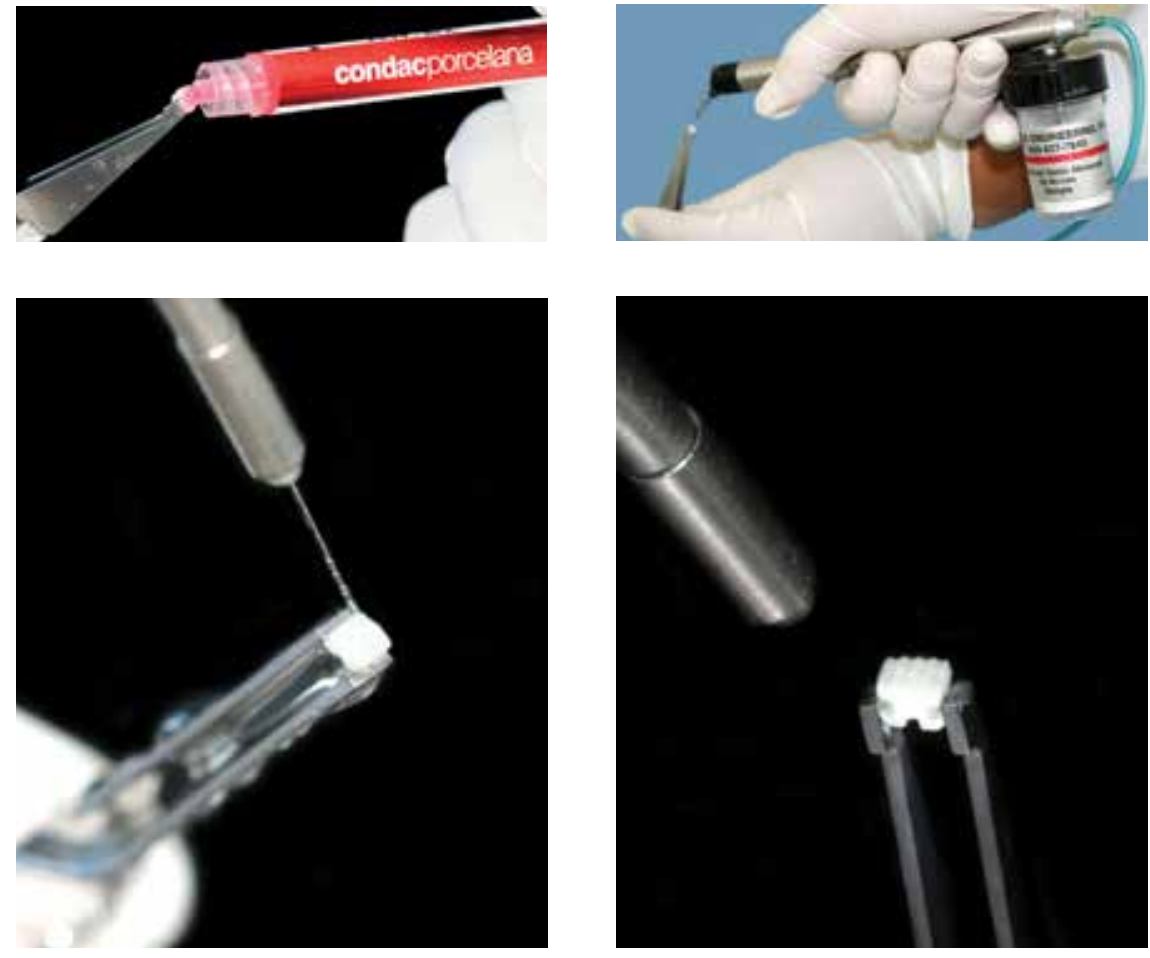

Figure 5 - Application of $10 \%$ hydrofluoric acid followed by rinsing, drying and blasting.

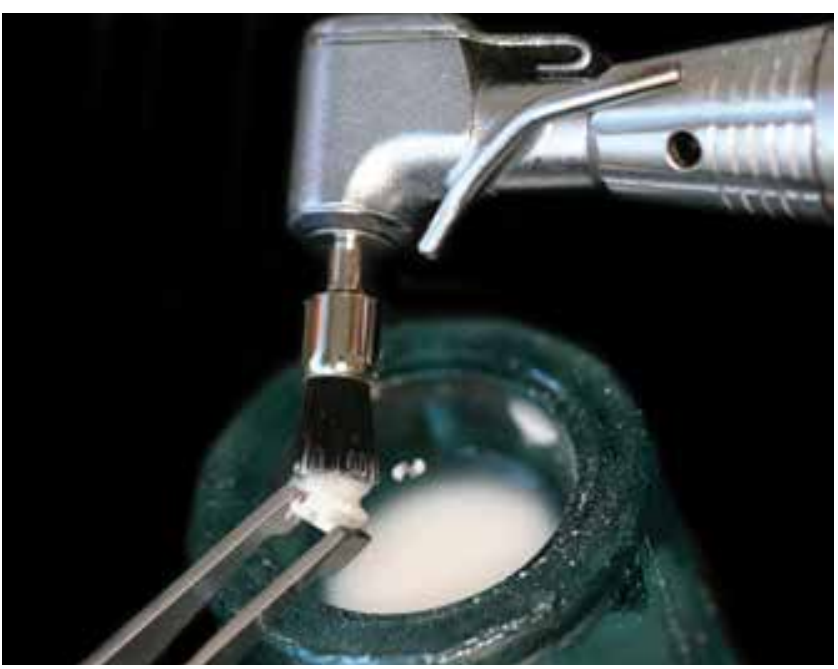

Figure 6 - Prophylaxis with brush and pumice.

Continuing with the surface treatments on Groups I, II and III, it was applied a silanization agent (Dentsply) and carried out a 15 seconds drying with air spray, followed by application of two layers of primer and removing excess with absorbent paper (Fig 7).

In the surfaces of the composite discs it was performed etching with $37 \%$ phosphoric acid for 30 seconds, followed by rinsig, drying and application of primer (Fig 8).
After completion of the different types of surface treatments on the ceramic brackets base, it was immediately applied the Transbond ${ }^{\mathrm{TM}}$ XT cement (3M Unitek) on the base of brackets that had been positioned and fixed in the center of the composite block with a bracket holding tweezer (Fig 9). The composite excess was removed with an explorer probe and polymerized for 40 seconds using the led device Optilight LD III (Gnatus, Brazil), with light intensity of $470 \mathrm{~mW} / \mathrm{cm}^{2}$.

Then the specimens were stored in distilled water in an oven for 24 hours at $37^{\circ} \mathrm{C}$.

All samples underwent a shear testing in a universal testing machine MTS 810 Material Test System, with proper supervision and guidance in the mechanical testing laboratory of the Department of Mechanical Engineering at the University of Brasília (UNB), with speed of $0.5 \mathrm{~mm} /$ minute and a load cell of $100 \mathrm{~N}$ (Fig 10). Then it was calculated the value of shear strength in $\mathrm{kgf} / \mathrm{cm}^{2}$, using the formula:

$\mathrm{R}=\mathrm{F} / \mathrm{A}$, where:

$\mathrm{R}=$ shear strength $\left(\mathrm{kgf} / \mathrm{cm}^{2}\right)$.

$\mathrm{F}=$ load required to break the union bracket/composite (kgf).

$A=$ area of the bracket base $\left(\mathrm{mm}^{2}\right)$. 

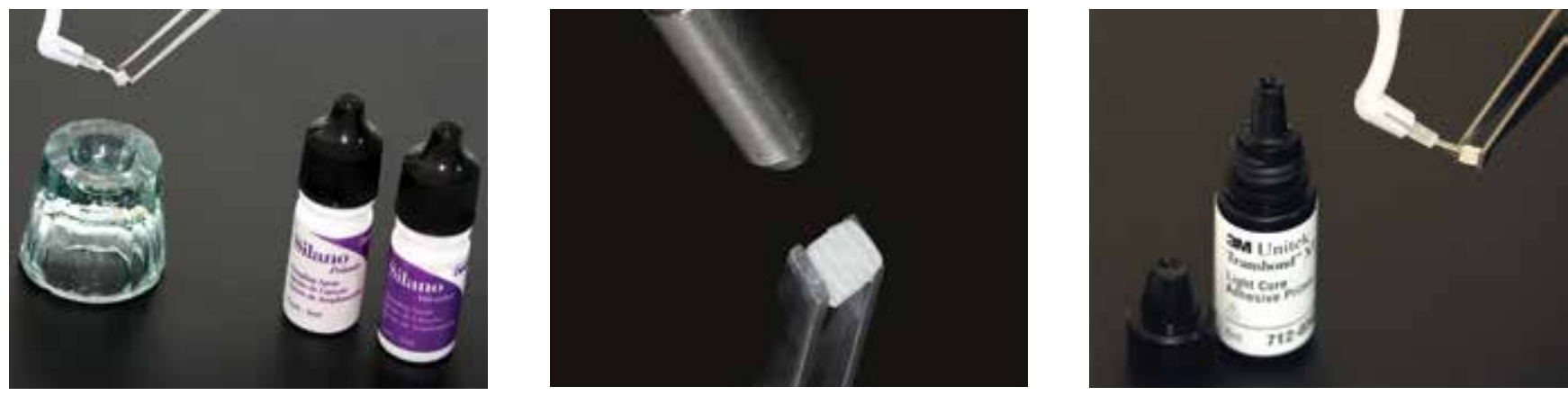

Figure 7 - Application of silanization agent, drying and primer application.
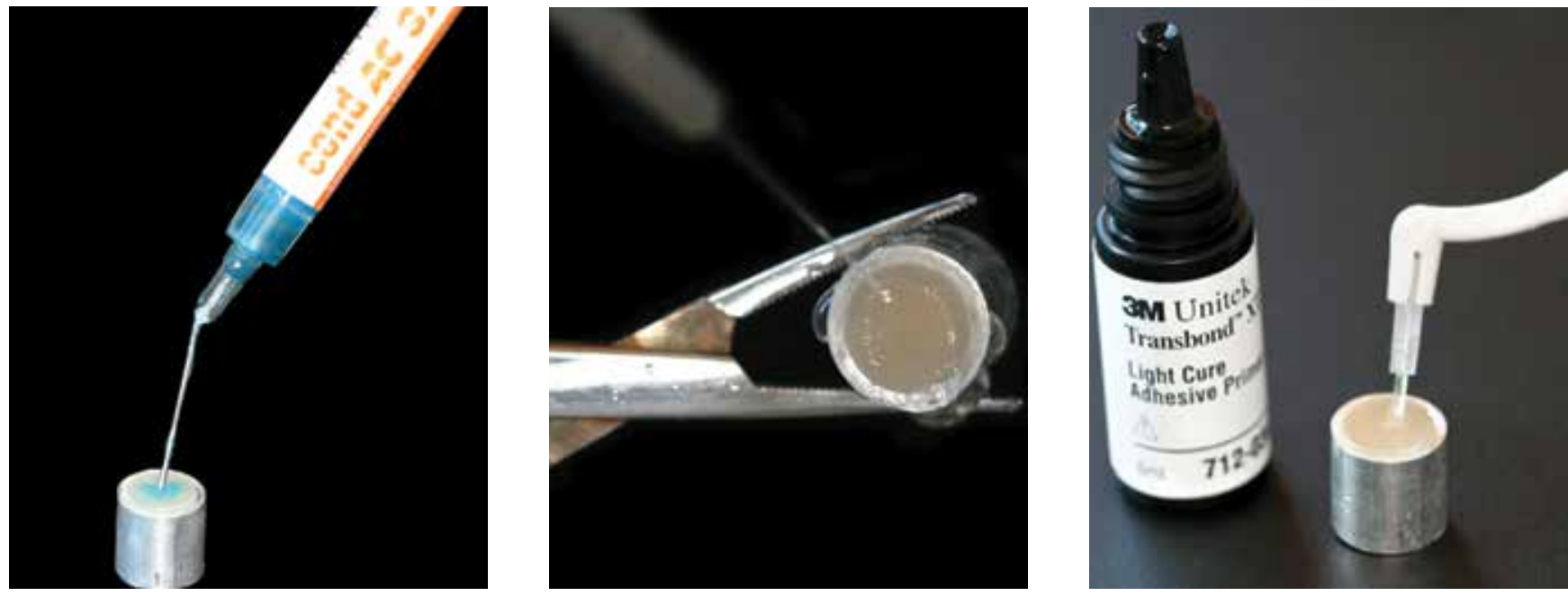

Figure 8 - Etching with 37\% phosphoric acid, rinsing and primer application on the composite resin disc.
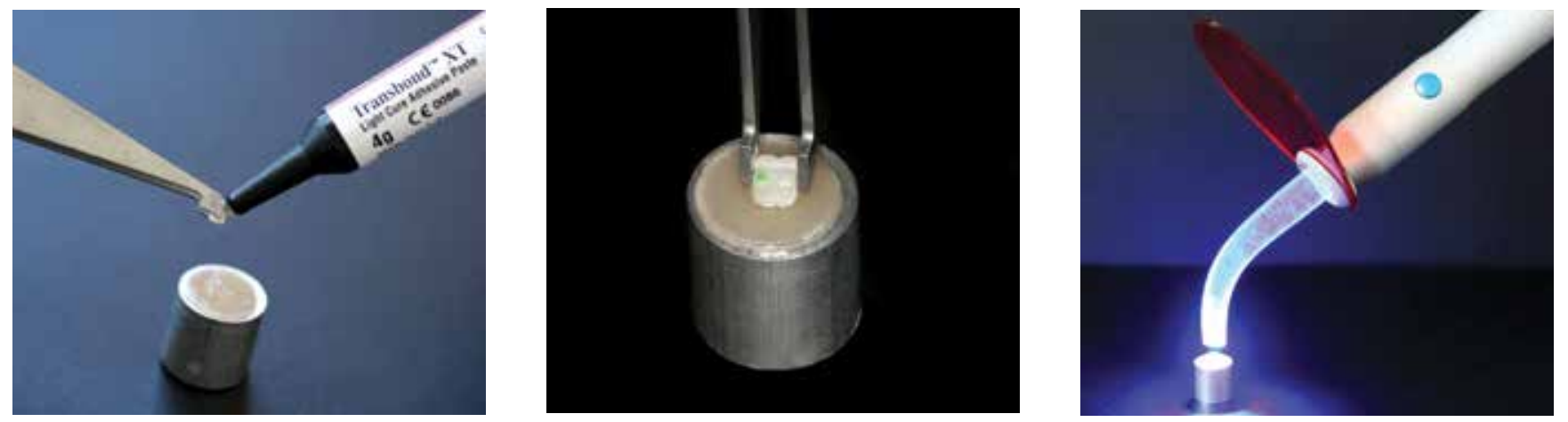

Figure 9 - Transbond ${ }^{\text {TM }} X T$ cement application and light curing with LED.

The tension values of shear strength were converted to Megapascal (MPa) and the values in MPa were submitted to the statistical test of better convenience according to the obtained results. 
Figure 10 - A) Universal testing machine MTS 810 Material Test System B) Moments before rupture of the adhesive bond of the ceramic/composite interface.
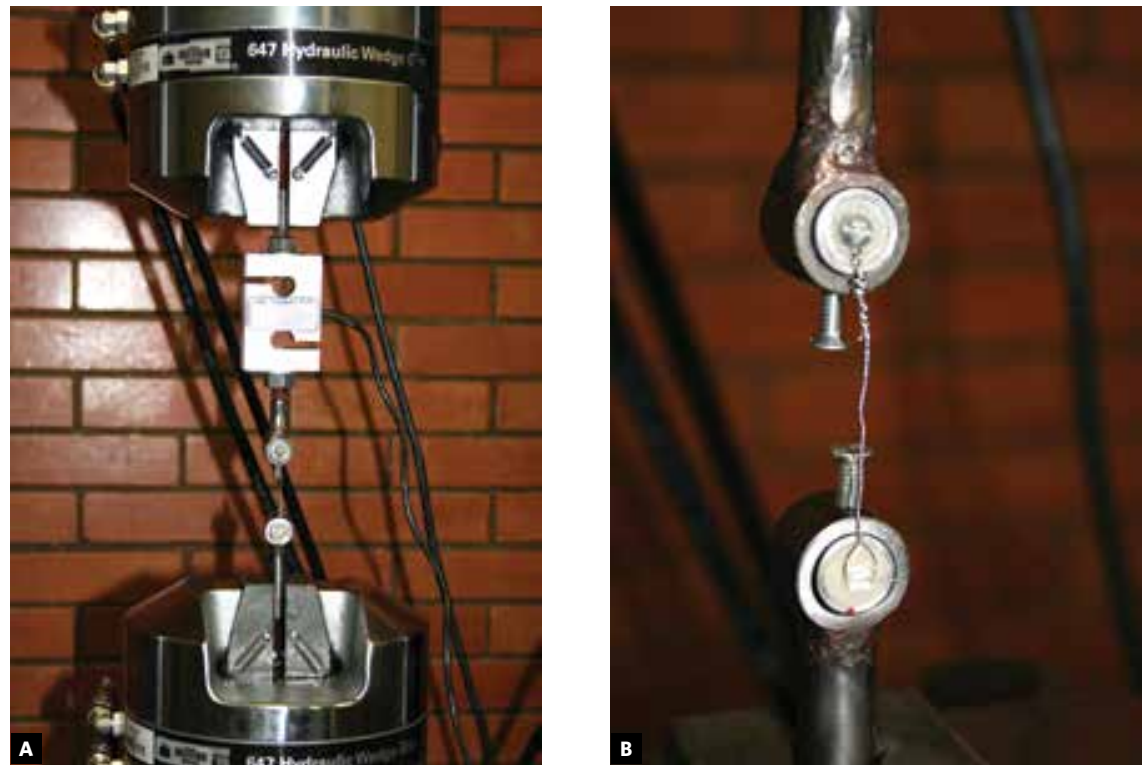

Table 1 - Evaluation of shear bond strength of different treatments on the surface of ceramic bracket to fixation in composite resin.

\begin{tabular}{ccc} 
Groups & Mean (MPa) & Standard deviation (SD) \\
I & $6.91 \mathrm{a}^{\star}$ & 1.76 \\
II & $7.59 \mathrm{a}^{\star}$ & 0.98 \\
III & $8.16 \mathrm{~b}$ & 0.89 \\
IV & $6.08 \mathrm{c}$ & 1.72 \\
\hline
\end{tabular}

* Groups with the same letter do not differ statistically. ANOVA and Tukey tests.

\section{RESULTS}

For statistical analysis purposes, the results of mechanical tests (shear bond tests) were subjected to analysis of variance (ANOVA) and comparison of means (Tukey $1 \%$ probability) (Table 1 ).

\section{DISCUSSION}

The success of the bonding of polymeric materials in orthodontics involves the combination of three basic factors, such as the mechanical conditioning (mechanical retention) or chemical conditioning of a surface, or a combination of both, the appropriate choice and proper handling of bonding materials and the retentive potential of accessories or brackets to be used. ${ }^{20,21}$ The substrate type (enamel, ceramic, composite, amalgam or metal alloys) and the clinical needs (type of movement to be used) are other important aspects to be considered to determine the necessary procedures in order to perform the conditioning of the adherent surface and select the type of adhesive system to be used in the bonding technique.

Since the introduction of acid etching on enamel surface, by Buonocore in 1955, several areas of dentistry have adopted this approach. In orthodontics, this finding provided development and clinical application by bonding orthodontic accessory directly on the enamel surface, eliminating the use of bands. The practice of bonding brackets by adhesive restorative system is widely used by orthodontists, which proves its effectiveness and acceptance.

Many improvements were developed attempting to enhance this connection, such as changes in the design of bases - with mesh screen, ${ }^{1,5,6}$ perforations, ${ }^{6,26,4}$ or grooves ${ }^{2,7,17}$ - and more recently, the blasting on the bracket base, ${ }^{18,23,27}$ applying other bonding agents, ${ }^{3,18}$ and the type of composite used. Despite all efforts, this adhesive interface remains critical in terms of bonding strength and durability in the oral environment.

A device coupled to the handpiece (micromechanical conditioner, Microetcher) allowing the blasting of dental or metal surfaces with aluminum oxide (25$100 \mu \mathrm{m}$ diameter) was first indicated to repair metalceramic or metal-plastic restorations, and therefore allowed the silanizing and bonding of the composite resin to the metal alloys. ${ }^{16}$ Subsequently, its use was extended to the sealing of pits and fissures, repair of 
ceramic or composite resin restorations, and currently, to make more retentive enamel surfaces in large adhesives restorations. ${ }^{16}$ Recently, the blasting of brackets bases was suggested by some authors ${ }^{23,27}$ and associated with other chemical agents. ${ }^{3}$ These results showed that the aluminium oxide blasting produces a considerable increase in the resistance of bonding between composite and ceramic material (7.59 MPa) probably due to increased surface irregularities.

Another option for improving the bond between composite and ceramic materials is to use hydrofluoric acid, which characterizes a acidified surface that allows the formation of hydroxyl groups $(\mathrm{OH})$ on the surface, to which some hydrogen molecules of water are united after pretreatment with silane, forming $\mathrm{O}$ - radicals on the porcelain surface, which will unite with the silane radical $\mathrm{Si}+{ }^{13}$ The results of this study showed that using $10 \%$ hydrofluoric acid on the surface of the ceramic bracket favored the increase of bonding resistance (6.91 MPa), because also promoted irregularities, and consequently retentions. The difference between the mechanical retention obtained applying hydrofluoric acid and aluminum oxide blasting is the depth of these retentions (irregularities).

The ceramic surface treatment aims to modify its texture, making it retentive and chemically compatible with the composite. The ceramic has as its main component, silicon oxide $\left(\mathrm{SiO}_{2}\right)$ and other oxides. For a proper adhesion, the chemical interaction between the constituent components of the silane and ceramics is important. According to $\mathrm{Suh}^{25}$ in 1991, the ceramic surface, although rich in glassy materials partially exposed, does not enable the silane to fully cover these particles, but reacts with the exposed portions. The high levels of silica in ceramic allow the "silanes" bonding agents to chemically adhere to the conditioned ceramic and the composite resin.

The present results showed that all types of treatment used are situated in a range of values that allows its clinical use. This can be evidenced by the study of Kydd et $\mathrm{al}^{11}{ }^{11}$ that found values strong enough to support the forces exerted by the archwires on the teeth during orthodontic treatment and by the minimum strength of 6-8 MPa found by Reynolds ${ }^{22}$ and Kydd et al. ${ }^{11}$

The surface treatment of the Group III (8.16 MPa) showed the best result of shear bonding strength in relation to Group IV (6.08 MPa) and the other groups, due to the ceramic surface treatment in order to modify the texture, making it retentive, and chemically compatible with the composite resin. The main factor that contributed to the increase of the union resistance values on Group III was the combined retention methods, promoted by different types of surface treatment. The correct time of application, concentration of the treating agent and appropriate technique influence directly the union resistance of these materials.

On the other hand, no differences were observed between Groups I (6.91 MPa) and II (7.5 MPa), due to the fact that the creation of retentions present numerically different depths, but statistically similar.

\section{CONCLUSIONS}

According to the methodology used and after analysis and discussion of results, we reached the following conclusions regarding the types of surface treatment on ceramic brackets bases:

1) The $10 \%$ hydrofluoric acid conditioning for $1 \mathrm{~min}-$ ute, followed by $50 \mu \mathrm{m}$ aluminum oxide blasting, silane application, and primer application, was considered the best method for ceramic brackets surface preparation prior to orthodontic esthetic bonding, because it provides a more effective and appropriate bond strength when compared to the control group.

2) Implementation of prophylaxis with brush and pumice, rinsed for 30 seconds and dried with oil-free air spray (control group) on ceramic brackets bases showed lower bond strength compared to other groups.

3) With regard to the type of treatment performed on the base of the brackets in Groups I and II, it was not found statistically significant differences, being 6.91 MPa and 7.5 MPa, respectively. 


\section{REFERENCES}

1. Alexandre P, Young J, Sandrik JL, Bowman D. Bond strength of three orthodontic adhesives. Am J Orthod. 1981 Jun;79(6):653-60.

2. Beltrami LER, Freitas CA, Martins DR. Bráquetes com sulcos retentivos na base, colados clinicamente e removidos em laboratório por testes de tração, cisalhamento e torção. Ortodontia. 1996;29(2):27-39.

3. Bishara SE, Ajlouni R, Laffoon J, Warren J. Effects of modifying the adhesive composition on the bond strength of orthodontic brackets. Angle Orthod. 2002 Oct;72(5):464-7.

4. Burstone CJ. The integumental profile. Am J Orthod Dentofacial Orthop. 1958;44(1):1-25.

5. Buzzitta VA, Hallgren SE, Powers JM. Bond strength of orthodontic direct-bonding cement-bracket systems as studied in vitro. Am J Orthod. 1982 Feb;81(2):87-92.

6. Dickinson PT, Powers JM. Evaluation of fourteen direct-bonding orthodontic bases. Am J Orthod. 1980 Dec;78(6):630-9.

7. Ferguson JW, Read MJ, Watts DC. Bond strengths of an integral bracket-base combination: an in vitro study. Eur J Orthod. 1984 Nov;6(4):267-76.

8. Gonzalez MN. Bráquetes cerâmicos [Monografia de Especialização]. Bauru (SP): Associação Paulista de Cirurgiões Dentistas; 2003.

9. International Organization for Standardization. Guidance on teting of adhesion to tooth structure: ISO/TC106/SC 1 N236, Resolution 61. - CD TR 11405. Trieste (IT): 1999.

10. Kao EC, Eliades T, Rezvan E, Johnston WM. Torsional bond strength and failure pattern of ceramic brackets bonded to composite resin laminate veneers. Eur J Orthod. 1995 Dec;17(6):533-40

11. Kydd WL, Akamine JS, Mendel RA, Kraus BS. Thogue and lip forces during deglution with an without an anterior open bite. J Dent Res. 1963 MayJun;42:858-66.

12. Lai PY, Woods MG, Tyas MJ. Bond strengths of orthodontic brackets to restorative resin composite surfaces. Aust Orthod J. 1999 Apr;15(4):235-45.

13. Lu R, Harcourt JK, Tyas MJ, Alexander B. An investigation of the composite resin/ porcelain interface. Aust Dent J. 1992 Feb;37(1):12-9.

14. Maltagliati LA, Feres R, Figueiredo MA, Siqueira DF. Bráquetes estéticos considerações clínicas. Rev Dent Press Ortodon Ortop Facial . 2006;5(3):89-95.

15. Mondelli AL. Estudo comparativo da resistência adesiva da interface resina/ bráquete, sob esforços de cisalhamento, empregando três resinas compostas e três tipos de tratamento na base do bráquete [Dissertação]. Bauru (SP): Universidade de São Paulo, Faculdade de Odontologia; 2004.
16. Mondelli AL, Freitas MR. Estudo comparativo da resistência adesiva da interface resina/braquete, sob esforços de cisalhamento, empregando três resinas compostas e três tipos de tratamento na base do braquete. Rev Dent Press Ortodon Ortop Facial . 2007:12(3):111-25.

17. Murray JJ, Bennett TG. Atlas colorido sobre técnica do ataque ácido. São Paulo: Manole; 1987.

18. Newman GV, Sun BC, Ozsoylu SA, Newman RA. Update on bonding bracketes: an in vitro survey. J Clin Orthod. 1994 Jul;28(7):396-402.

19. Pinto AS, Pinto LAMS, Cilense M, Melo ACM, Terra AMV. A reciclagem de bráquetes na clínica ortodôntica. Ortodontia. 1996;.29(2):63-7.

20. Profitt WR, Fields HW. Ortodontia comtemporânea. 2a ed. Rio de Janeiro: Guanabara Koogan; 1995. Cap. 12, p. 322.

21. Reynolds IR, Von Franhofer JA. A review of direct orthodontic bonding Br J Orthod 1975:2(3):171-8.

22. Reynolds IR, von Fraunhofer JA. Direct bonding of orthodontic attachmentes to teeth: the relation of adhesive bond strength to gauze mesh size. Br J Orthod. 1976 Apr;3(2):91-5.

23. Sant'Anna EF, Monnerat ME, Chevitarese O, Stuani MB. Bonding brackets to protcelain - in vitro study. Braz Dent J. 2002;13(3):191-6.

24. Santos PCF, Santos JFF, Vigorito JW, Miranda Júnior WG, Gomes, W. Avaliação da capacidade de retenção de bráquetes cerâmicos e metálicos colados em ambiente úmido. Ortodontia. 2000;33(1):21-34

25. Suh BI. All-Bond-Fourth generation dentin bonding system. J Esthet Dent. 1991 JulAug;3(4):139-47.

26. Thanos CE, Munholland T, Caputo AA. Adhesion of mesh-base direct-bonding brackets. Am J Orthod. 1979 Apr;75(4):421-30.

27. Velasquez NZ. Estudo comparativo das uniões bráquete-resina-esmalte bráquete-resina-cobre-alumínio; bráquete-resina-níquel-cromo; bráqueteresina-porcelana. Mediante testes de cisalhamento utilizando as resinas Enforce e Concise [Dissertação]. Bauru (SP): Universidade de São Paulo, Faculdade de Odontologia; 1998.

28. Wang WN, Meng CL, Tarng TH. Bond strength: a comparison between chemical coated and mechanical interlock bases of ceramic and metal brackets. Am J Orthod Dentofacial Orthop. 1997 Apr;111(4):374-81. 